\title{
Cellular Telephone Use: A Survey Of College Business Students
}

\author{
Kay H. Braguglia, Hampton University
}

\begin{abstract}
Whether it is hand held, in a pocket, on a backpack, clipped to a belt, or hidden in a brief case or purse, college students and cellular telephones go together. Communication with fellow students, professors, parents, and everyone else is just a click away. While walking across campus and down the halls of academic buildings, cellular telephones are being used. This research questions in what ways do students use cellular telephones and does this use interfere with or assist in learning and college life? This paper reports the results of a survey of undergraduate business students addressing this question. The objectives were to determine: (1) how much time is spent using a cell phone and which phone features are used most frequently, (2) what students believe concerning the impact of cell phones on learning in the classroom and during study, (3) how often students are in contact with parents on a cell phone, and (4) how much do students pay for cell phone services. The results indicate that $100 \%$ of the students own a cell phone. Sixty-six percent of the students use voice calls most frequently and $30 \%$ use text messages most often. A total of $55.8 \%$ of students report that they spend 3 hours or less on their cell phone daily and $44.8 \%$ spend four or more hours daily on their cell phones. Over half of the students report that they have some interaction with their cell phones during class time for every class. Seventy-seven percent state that this cell phone use seldom or never interferes with classroom learning. All of the students (100\%) believe that they should be able to receive emergency information over a cell phone during class time. Seventy-six percent believe that cell phones seldom or never assist in classroom learning. However, students report that cell phone use impacts on study time outside of class. Cell phone distractions during study time outside class was reported by $34.6 \%$ of the students as happening often or always and an additional $43.5 \%$ are sometimes distracted by cell phones during study time. Bad or upsetting news received over a cell phone before class impacts academic performance of $14.2 \%$ of the students often or always. Thirty-five percent of the students talk to parents more than once a day and another $23.7 \%$ have contact on a daily basis. Therefore, 59.5\% report that they have contact with their parents at least once a day. Fifteen percent of the students pay over $\$ 100$ per month for cell phone service, 28\% pay from $\$ 75$ to $\$ 100,34 \%$ spend $\$ 51$ to $\$ 75$, and $14 \%$ spend $\$ 26$ to $\$ 50$ per month. More than $90 \%$ of the students report that they have text messaging, calculator, clock, calendar, and appointment reminder on their cell phone. Over 70\% have the internet and games. Over 60\% have a camera and email. Only 13\% have an MP3 music player and 7\% have an FM radio.
\end{abstract}

Keywords: cellular telephone use and college students.

\section{INTRODUCTION}

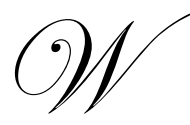

hether it is hand held, in a pocket, on a backpack, clipped to a belt, or hidden in a brief case or purse, college students and their cellular telephones go together. Communication with fellow students, professors, parents, and everyone else is just a click away. While walking across campus and down the halls of academic buildings, cellular telephones are being used. Rules concerning the use of cellular telephones are written in course syllabi, posted in doorways, and addressed in university policies. This research questions in what ways do students use cellular telephones and does this use interfere or assist in learning and college life? This paper reports the results of a survey of undergraduate business students addressing this question. The objectives 
were to determine: (1) how much time spent using a cell phone and which phone features are used most frequently, (2) what students believe concerning the impact of cell phones on learning in the classroom and during study, (3) how often students are in contact with parents on a cell phone, and (4) how much do students pay for cell phone services.

\section{LITERATURE REVIEW}

College students are fluent in the digital language of computers, cellular telephones, video games, and the Internet. By the time a typical student enters college they have spent over 10,000 hours playing videogames, over 10,000 hours talking on digital cell phones; over 20,000 watching television, and received or sent over 200,000 emails and instant messages. At the very most, they have spent 5,000 hours of book reading (Prensky, 2001). The use of cell phones is so pervasive that two students can be seen standing face to face talking to each other on their respective cell phones. Or a coed can be heard after accidently dropping and breaking a cellular telephone that it was her "life".

Research suggests that people feel the phone is part of them and that they are not whole without their phones since the phones connect them with the outside world. Many heavy users of mobile phones report feeling vibrations when there are none, or feeling as if they are wearing a cell phone when they're not. The phenomenon of phantom vibrations has been termed "fauxcellarm". Students can become so tapped into community responsiveness that they are constantly scanning and scanning to see if they have to respond to someone socially. Some see phantom vibrations as a point of pride and for others it's just another technological irritation (Simon, 2007).

Cell phones have changed the appearance of the college student. Carrying a cell in their hand or as a headset for quick response to a call is typical. Surveys and sale numbers show that young shoppers are shunning watches in favor of using cell phones to tell time. Watch sales declined 11 percent in 2006 and many in the cell phone generation see watches as relevant as grandfather clocks. Bare wrists are plentiful on college campuses (Eagan, 2006).

Many college professors ban the use of cellular telephones in their classroom. The reason given is the distraction to the learning process and compromising examinations. Until recent years, students cheated by writing on their palms, sneaking notes up their sleeves or whispering answers to classmates. With cell phones, cheating has turned high tech. Students can text messages of answers to tests, take pictures of tests or search the internet for answers. In college and some high schools, students are allowed to have phones but are required to keep them turned off and out of sight. Despite rules about cell phones, students still use them during the school day. Some teachers give warnings, others confiscate the phones. Sometimes cell phones are collected in basket at the door before a test. Some give zeros to any student caught with a phone during and examination. Many assume that the student is cheating if they have a cell phone out during a test (Walson, 2006).

Some of the rules against cellular phones in the classroom are being revised. After 32 students were killed on the Virginia Tech campus in April 2007, the University has instituted "VT Alerts". This system uses cell phone text messages, voice mail, email, and online instant messages for alerts. Nearly 18,000 students, faculty, and staff subscribed to the system since it was launched (Gelineau, 2007). Many colleges and universities have revised the way emergency alerts are sent to the college community.

Not only can the cell phone be used for emergency alerts on college campuses, some researchers believe that cell phones have potential to assist in the learning process. Researchers indicate that one of the most important tools for the $21^{\text {st }}$ century students is not the computer, but the cell phone that so many classroom instructors currently ban. Cell phones have enormous capabilities: voice, text messaging, graphics, browsers, camera functions, geo-positioning, sensors, plug-in screens, headphones, fingerprint readers, and voice recognition. Mobile phones could replace textbooks in the future and with the limited screen size publishers will reformat information for maximum effectiveness rather than just added pages (Prensky, 2006). In Europe, China, Japan, and the Philippines, the public is already using mobile phones as learning tools. One opinion is that educators in the United States need 
to join them and overcome objections that students are using cell phones for cheating or for inappropriate picture taking (Pensky, 2005/2006).

However, research shows that the adaptation of cell phone technology differs around the world and different technology adoption patterns reflect culture. While U.S. consumers use their cell phones primarily as a communication tool to simply talk or send text messages, in other countries cell phones are increasingly used to help manage spiritual, social, and everyday needs. In Japan, cell phones can be used to pay for purchases in many stores. Consumers simply wave their phones in front of electronic readers to pay for purchases. This is a mini credit card service and the charges are tacked onto monthly phone bills. In India, a wireless carrier joined with a bank to offer smart chips that eliminate need for wallets and cash registers. Merchants send consumers a text message with purchase amount and consumers enter a personal identification number to authorize deduction of the sale from their bank account. In China, coupons redeemable at McDonald's restaurants can be received by phone. In Singapore, road tolls and parking tickets can be paid with a phone. In Korea, subscribers to an online dating service can receive alerts when they are near a potential match and send a text message. In China, singles flirt anonymously over the phone but they skip the text messages and go straight to voice calls. As part of an online social network, calls are placed through a special phone service using an identification code. In several countries, cell phones are used for a spiritual connection through text messaged prayers and tracking prayer schedules. In India, text messages can be sent to the temple for a Hindu god and worshippers can track how many times they have prayed to any of 18 gods. A service for Muslim worshippers worldwide allows user to download an application that enables their cell phone to display the direction of Mecca, Islam's holiest site as well as send an alert for the five daily calls to prayer (Tasi, 2006). Africa had the world's fastest growing cell phone market from 1999 to 2004 , where cell phones are a technological revolution enabling millions of people to improve their social and economic life (LaFraniere, 2005). For some Asian consumers, MySpace and Facebook are going mobile. The new service will make it possible to update the blogs or search for others phone numbers and email addresses from a cell phone (Yuan \& Buckman, 2006). Puzzle and action games come with most mobile devices but coming next to cell phones are games that require players to race around real life cities hunting for other players to "tag" and games that challenge sports fans to guess the next moves of athletes. These new games encourage players to interact in the physical world or with other media, such as television (Wingfield, 2006).

In the United States, companies have duplicated these services. In fact, the cell phone, or more accurately the device formerly known as the cell phone is getting more and more like a little portable computer. High end models can handle large volumes of email, complete with attachments; surf the Web at high speed; view and edit Microsoft Office documents; take decent pictures; and play back music and videos. They have spacious memory cards and small usable keyboards instead of mere phone keypads (Mossberg \& Boshert, 2006). The world's largest internet search firms, Google, Yahoo, and Microsoft want their search engines and logos to pop up on cell phone screens, enabling people to use their phones for other services the companies provide. Even though only a small number of people currently use their phones to search for information online, there is a huge potential market with twice as many cell phones in use globally as PCs. Many companies are building mobile friendly Web sites making if easier for cell phones to exact only key information (Bryan-Low \& Delaney, 2006).

While the potential may exist, Americans pay on average $\$ 50$ per month for cell phone service (Svensson, 2006). Many cell phone subscribers are not willing to pay for duplication of services they already have on personal computers. Cell phone extras like downloading music, internet access, or playing videos are not as popular as some wireless companies had hoped. Thus far, prices and monthly fees have been a barrier to experimentation and use. For example, only $1 \%$ of mobile customers watch video on their phones and the figure is expected to rise to only $5 \%$ by 2010 (Benderoff, 2006).

Presently, college students use cell phones as a personal communication device with voice and text messaging. One primary use is to communicate with parents. A survey of college students found an average of 10.41 communications per week over cell phone and text messaging. In this study, parents initiated most of the contact (Kantrowitz \& Tyre, 2006). 
The possibilities of educational applications for cell phones are enormous and emerging. At this time, little research has been conducted on the use of cell phones in the college classroom. This study will help to identify present use and opinions of college students toward cell phones in the classroom.

\section{THE STUDY}

Undergraduate students in a School of Business were surveyed in the spring semester of 2007. The school has an enrollment of 1,150 full time undergraduate students in eight areas including accounting, business administration, economics, entrepreneurship, management, marketing, and finance. A sample of 84 of the students participated in this research. Forty six were female and 38 were male. The typical student is of traditional college age. In this study, 26 were from 17 to 20 years and 58 were from 21 to 24 . The study included no freshmen, 4 sophomores, 48 juniors, and 32 seniors. Cluster sampling was used to identify participants. All management courses offered during the spring semester 2007 were listed and from this list a random selection of four courses was made.

A questionnaire was developed for this study. Completion of the questionnaire required about ten minutes and employed a self-reporting, paper and pencil format. Questionnaires were given to all the participants during a class period. They were briefly informed about the research project and were assured that their responses would remain anonymous and confidential. The surveys were given out and collected back at the beginning or end to the class period. A total of 84 questionnaires were completed by business majors. Questionnaires completed by nonbusiness majors were disregarded. Each questionnaire was tallied and categorized. The data were summarized and percentages were calculated.

\section{SURVEY RESULTS}

The results indicate that $100 \%$ of the students surveyed own and use a cell phone. The amount of time students spend using a cell phone varies from less than an hour to more than 10 hours daily. Over fourteen percent use their cell phone less than an hour, $41.6 \%$ from one to three hours, $23.5 \%$ from four to six hours, $15.4 \%$ from seven to nine hours, and $5.9 \%$ for 10 or more hours daily. The data indicates that a total of $55.8 \%$ of the students report that they spend 3 hours or less on their cell phone daily and $44.8 \%$ spend four or more hours daily on their cell phones.

Table 1

Daily Hours Spent on Cell Phones

\begin{tabular}{|c|c|c|c|c|}
\hline Less than 1 hour & $\mathbf{1 - 3}$ hours & $\mathbf{4 - 6}$ hours & $\mathbf{7 - 9}$ & $\mathbf{1 0}$ or more \\
\hline 14.2 & 41.6 & 23.5 & 15.4 & 5.9 \\
\hline
\end{tabular}

Note: Tabled values are percentages and may not equal 100 due to rounding

Voice calls are the most frequently used cell phone feature with $66.2 \%$ of the students indicating this choice. Text messaging was the choice for 30.1 percent of the students. The internet was most frequently used by $3.6 \%$ of the students and $1 \%$ indicated the use of email. None of the students indicated that they used their cell most frequently for music or games.

Table 2

Most Frequent Use of Cell Phone

\begin{tabular}{|c|c|c|c|c|c|c|}
\hline Voice Calls & Text Messages & Music & Games & Internet & Email & Other \\
\hline 66.2 & 30.1 & 0 & 0 & 3.6 & 1 & 0 \\
\hline
\end{tabular}

Note: Tabled values are percentages and may not equal 100 due to rounding 
A total of $53.5 \%$ of the students indicated that they interact with their cell phone during class time in every class they attend. Other students reported less frequent use during class with $28.5 \%$ using their phone once a day, $3.5 \%$ weekly, $1.1 \%$ monthly and $14.2 \%$ never.

Table 3

Cell Phone Used During Class

\begin{tabular}{|c|c|c|c|c|}
\hline Every Class & Once a Day & Weekly & Monthly & Never \\
\hline 53.5 & 28.5 & 3.5 & 1.1 & 14.2 \\
\hline
\end{tabular}

Note: Tabled values are percentages and may not equal 100 due to rounding

The majority of students do not believe that cell phone use either interferes or assists them with learning while in the classroom. The impact of cell phone use on learning in the classroom indicates that $77.3 \%$ of students believe that using a cell phone during class seldom or never interferes with classroom learning. Whereas $16.6 \%$ believe that their cell phone interferes sometimes and $7.1 \%$ believe that the phone often or always interferes with their learning during class. On the other hand, a total of $76.1 \%$ of students believe that cell phones seldom or never assist them with learning during class. Only $4.6 \%$ indicate that cell phones often or always assist them while in class.

Students report that cell phones are a distraction during study time outside of class and they tend to believe that cell phones do not assist them in learning. Responses to the impact of cell phones on learning during study time outside of class indicated that $34.6 \%$ are often or always distracted, $43.5 \%$ are sometimes distracted, and $22.8 \%$ are seldom or never distracted from study by cell phone use. More than half of the students $(60.6 \%)$ report that cell phones seldom or never assist them in their learning outside of class. A smaller percentage (13.9\%) finds that a cell phone assists with learning outside of class.

Bad or upsetting news received over a cell phone effects the ability to concentrate for $14.2 \%$ of students often or always just before class. Another $35.7 \%$ indicate that upsetting news affects them sometimes. One half of students $(49.9 \%)$ are seldom or never affected by bad news before class.

Table 4

Impact of Cell Phone Use on Learning

\begin{tabular}{|c|c|c|c|c|c|}
\hline Item & Always & Often & Sometimes & Seldom & Never \\
\hline $\begin{array}{l}\text { How often does the use of your cell phone during class } \\
\text { interfere with your learning? }\end{array}$ & 2.3 & 4.7 & 16.6 & 47.6 & 29.7 \\
\hline $\begin{array}{l}\text { How often does the use of your cell phone during class assist } \\
\text { in your learning? }\end{array}$ & 1.1 & 3.5 & 20.2 & 22.6 & 53.5 \\
\hline $\begin{array}{l}\text { How often does the use of your cell phone during study time } \\
\text { outside of class distract you? }\end{array}$ & 13 & 21.6 & 43.3 & 16.8 & 6 \\
\hline $\begin{array}{l}\text { How often does the use of your cell phone during study time } \\
\text { outside of class assist you in learning? }\end{array}$ & 2 & 11.9 & 26.1 & 29.7 & 30.9 \\
\hline $\begin{array}{l}\text { How often does bad or upsetting news received over your cell } \\
\text { phone just before class impact on your ability to concentrate? }\end{array}$ & 7.1 & 7.1 & 35.7 & 38 & 11.9 \\
\hline
\end{tabular}

Note: Tabled values are percentages and may not equal 100 due to rounding

Contact with parents more than once each day was reported by $35.7 \%$ of students and an additional $23.8 \%$ have contact once each day. A total of $59.5 \%$ of students are in daily contact with their parents. 
Table 5

Frequency of Cell Phone Contact With Parents

\begin{tabular}{|c|c|c|c|c|}
\hline More than once a day & Once a day & Weekly & Monthly & Never \\
\hline 35.7 & 23.8 & 39.2 & 2.3 & 0 \\
\hline
\end{tabular}

Note: Tabled values are percentages and may not equal 100 due to rounding

Sixty three percent of students spend from $\$ 51$ to $\$ 100$ for phone service each month. A smaller percentage $14.2 \%$ spent less than $\$ 50$ and $15.4 \%$ spend over $\$ 100$ each month.

Table 6

Monthly Payment for Cell Phone Use

\begin{tabular}{|c|c|c|c|c|c|}
\hline \$25 or Less & $\mathbf{2 6 - 5 0}$ & $\mathbf{5 1 - 7 5}$ & $\mathbf{7 5 - 1 0 0}$ & Over 100 & Don't Know \\
\hline 0 & 14.2 & 34.5 & 28.5 & 15.4 & 7.1 \\
\hline
\end{tabular}

Note: Tabled values are percentages and may not equal 100 due to rounding

Over $90 \%$ of students have text messaging, calculator, clock, and appointment reminder. Between 60 and $70 \%$ have the internet, email, games, and camera. Forty three percent have a headset.

Table 7

Cell Phone Features

\begin{tabular}{|l|c|l|c|}
\hline \multicolumn{1}{|c|}{ Cell Phone Feature } & \% With Feature & \multicolumn{1}{c|}{ Cell Phone Feature } & \% With Feature \\
\hline Clock & 94 & Games & 76 \\
\hline Calendar & 94 & Camera & 64 \\
\hline Text Messaging & 90 & Email & 63 \\
\hline Calculator & 90 & Head Set & 43 \\
\hline Appointment Reminder & 90 & MP3 Player & 13 \\
\hline Internet & 76 & FM Radio & 5 \\
\hline
\end{tabular}

\section{CONCLUSION}

This study reinforces the belief that college students are tremendous users of cellular telephones and that they use cell phones primarily as a communication tool to simply talk or send text messages. All of the students in the study indicated that they have a cell phone. Sixty-six percent of the students use voice calls most frequently and $30 \%$ use text messages most often. A total of $55.8 \%$ of students report that they spend 3 hours of less on their cell phone daily and $44.8 \%$ spend four of more hours daily on their cell phones.

While classroom instructors may prohibit the use of cell phones or require that they are turned off during class time, students still interact with their cell phones. A total of $53.5 \%$ of the students indicated that they interact with their cell phone during class time in every class they attend. While this interaction could be turning it off at the beginning of instruction or feeling it vibrate in a pocket, the cell phone is present. A total of $77.3 \%$ of students believe that using a cell phone during class seldom or never interferes with classroom learning. All of the students $(100 \%)$ believe that they should be able to receive emergency information over a cell phone during class time.

However, students believe that cell phones do distract them from study outside of class. Cell phone distractions during study time outside class was reported by $34.6 \%$ of the students as happening often or always and an additional $43.5 \%$ are sometimes distracted. 
Most college students do not use cell phones as a tool to assist with the learning process. Even with increasingly sophisticated technology available on cell phones, the majority of students report that they do not assist with learning either inside or outside the classroom. A total of $76.1 \%$ of students believe that cell phones seldom or never assist them with learning during class. Over one half of the students (60.6\%) report that cell phones seldom or never assist them with their learning outside of class.

Students are in frequently in contact with others especially parents. Thirty-five percent of the students talk to parents more than once a day and another $23 \%$ have contact once a day. This totals to $59.5 \%$ having contact at least once a day. Through this contact, parents become an active part in a college life. Sometimes contact with others affects student performance. Bad or upsetting news received over a cell phone before class impacts on the academic performance of $14.2 \%$ of the students always or frequently.

Cell phones have become an additional and expected expense while in college. Fifteen percent of the students pay over $\$ 100$ per month for cell phone service, $28 \%$ pay from $\$ 75$ to $\$ 100,34 \%$ spend $\$ 51$ to $\$ 75$, and $14 \%$ spend $\$ 26$ to $\$ 50$ per month. More than $90 \%$ of the students report that they have text messaging, calculator, clock, calendar, and an appointment reminder on their cell phone. Over $70 \%$ have the internet and games. Over $60 \%$ have a camera and email. Only 13\% have an MP3 music player and 7\% have an FM radio. With all these features on cell phones, college instructors must be careful that their teaching methods do not become like the wrist watch: outdated and so five minutes ago.

\section{REFERENCES}

1. $\quad$ Benderoff, E. (2006, August 7). Gadgets ring sour. The Daily Press, pp. C6-7.

2. Bryan-Low, C. \& Delaney, K. (2006, May 8). The next tech battle: Internet searches on cell phones. The Wall Street Journal, p. B1, B6.

3. $\quad$ Ernest, L. (2006, April 27). To many youths, a watch is so five minutes ago. The Daily Press, p. D1.

4. $\quad$ Gelineau, K. (2007, October 9). Virginia Tech to test system. The Daily Press, p. B5.

5. $\quad$ Kantrowitz, B. \& Tyre, P. (2006, May 22). The fine art of letting go. Newsweek. 49-64.

6. LaFraniere, S. (2005, August 25). Cell phones catapult Africa to $21^{\text {st }}$ century. New York Times. Retrieved July 12, 2007 from www.nytimes.com

7. Mossberg, W., \& Boshret, K. (2006, June 7). Smartphones get smarter. The Wall Street Journal, p. D1.

8. Prensky, M. (2001, December). Digital natives digital immigrants, part II: Do they really think differently? On The Horizon NCB University Press. 9(6).

9. Prensky, M. (2005/2006, December/January). Learning in the Digital Age. Educational Leadership, 63 (4), 8-13.

10. Prensky, M. (2006). What can you learn from a cell phone. Retrieved June 19, 2006 from www.mobile.kaya.com/mobile_learning

11. Simon, E. (2007, October 11). Missing cell phone causes "fauxcellarm". The Daily Press, p. C9.

12. Svensson, P. (2006, March 27). Wireless hotspot phone not there yet. The Daily Press, p. B5-7.

13. Tsai, M. (2006, June 19). What's a phone for? The Wall Street Journal, p. R12.

14. Walson, K., (2006, June 8). Teachers must worry about hi-tech cheats. The Daily Press, p. 12.

15. Wingfield, N. (2006, April 4) Beyond brick breaker. The Wall Street Journal, pp. D1, D2.

16. Yuan, L. \& Buckman, R. (2006, April 4). Social networking goes mobile. The Wall Street Journal, p. D1. 
NOTES 